Int. J. Morphol.,

31(2):777-784, 2013.

\title{
Ultrastructural Study of Bovine Papillomavirus During Outbreaks in Brazil
}

\author{
Estudio Ultraestructural del Virus Papiloma Bovino Durante Brotes en Brasil
}

Catroxo, M. H. B."; Martins, A. M. C. R. P. F.*; Petrella, S.**; Souza, F."; Nastari, B.D.B."

CATROXO, M. H. B.; MARTINS, A. M. C. P. F.; PETRELLA, S.; SOUZA, F.; NASTARI, B. D. B. Ultrastructural study of bovine papillomavirus during outbraeks in Brazil. Int. J. Morphol., 31(2):777-784, 2013.

SUMMARY: Papillomaviruses, belonging to the Papillomaviridae family, are small oncogenic viruses, causing papillomas and fibropapillomas in the mucosal and cutaneous epithelia of several animals. In bovine species, thirteen types (BPV 1-13) were characterized to date. In this study, the occurrence of papillomatosis in four outbreaks in cattle herds, coming from Brazilian states were registered. The papillomatous lesions were found located in the teats, udders, head and neck. Under the transmission electron microscope, by the negative staining technique, it was possible to visualized rounded-format papillomavirus, with icosahedral symmetry, characterized as "full" and "empty" particles, measuring on average $60 \mathrm{~nm}$ in diameter, in all the 40 samples observed of skin lesion fragments. The ultrathin sections revealed the presence of groups of viral, intranuclear, rounded particles measuring $35 \mathrm{~nm}$ in diameter and tubular particles with a diameter of 35-39 $\mathrm{nm}$. At immunoelectron microscopy technique, positivity obtained was marked by the presence of aggregates of viral particles formed by the antigen-antibody interaction. In the immunocytochemistry technique, the antigen-antibody reaction showed colloidal gold particles evenly distributed over the surface of the virus. These results showed the importance of the transmission electron microscopy techniques in the diagnosis of bovine papillomatosis that can be used in routine procedures to identify viral agent of this important disease.

KEYWORDS: Papillomavirus, Cattle, Transmission Electron Microscopy.

\section{INTRODUCTION}

Papillomaviruses are small oncogenic, non-enveloped and rounded viruses belonging to the Papillomaviridae family. These viral particles are characterized by their "full" and "empty" structures with diameters between 50 and $60 \mathrm{~nm}$. The capsid has a thickness of approximately $2 \mathrm{~nm}$ and contains capsomers with 72 morphological units, arranged in an icosahedral symmetry (Shah \& Howley, 1990; Van Regenmortel et al., 2000; Doorbar \& Sterling, 2001). The wellpreserved architecture of capsids was demonstrated through atomic model Paintsil, 1998; Modis et al., 2001).

The genome of these viruses consists of a doublestranded circular DNA with 7.2 to $8.0 \mathrm{Kbp}$ which encodes 8 to 10 proteins and contains three regions, long control, early and late regions. The early region encodes E1 to E8 nonstructural proteins with regulatory and replicative functions. The late region encodes two structural proteins L1 and L2 forming the capsid. The BPV-4 type codifies the L3 protein with an unknown function (Patel et al., 1987; Doobar \& Sterling, 2001).
The papillomatosis in humans and different animal species cause benign hyperproliferative lesions of both mucosal and cutaneous epithelium besides malignant tumors. In cattle, the infection is often associated with development of cutaneous papillomas and tumors of the gastrointestinal and urinary tracts (Corteggio et al., 2013).

Thirteen types of bovine papillomavirus (BPV-1-13) were described and classified into four genera. The deltapapillomavirus including BPV-1, 2 and 13 types induces fibropapilloma in bovine species and sarcoid in equine, the xi-papillomavirus which comprises the BPV-3, 4, 6, 9, 10, 11 and 12 types which infect only the epithelial papillomas, the epsilon- papillomavirus that includes the BPV- 5 and 8 types causing fibropapillomas and epithelial papillomas. Yet, the BPV-7 type does not belong to any of these genera (Ogawa et al., 2004; Dong et al., 2012).

It was concluded that BPV-1 and 2 comprises the major cutaneous fibropapillomas. The BPV-1 can induce

\footnotetext{
* Laboratory of Electron Microscopy, Biological Institute of São Paulo, Brazil.

** Adolfo Lutz Institute, São Paulo, Brazil.
} 
these lesions in teats and penis (Block et al., 1994; Campo, 1997; Jelinek \& Tachezy, 2005) while the bovine enzootic hematuria that affects digestory tract is related to BPV- 2 (Schuch, 1998; Wosiacki et al., 2002). Hatama et al. (2008) and Borzachiello \& Roperto (2008) demonstrated that the BPV-5, 9 and 10 lead to the development of fibropapillomas in the udder. The BPV 3 and 11 were isolated from skin epithelial papillomas of different body parts (Pfister et al., 1979; Hatama et al., 2011). Other experiments revealed in the epithelia of the digestory tract the presence of BPV-4 (Borzachiello \& Roperto, 2008) of teat the presence of BPV6 and 9 (Jarret et al., 1984; Hatama et al., 2008) of the tongue the BPV-12 (Zhu et al., 2012) and in ears the BPV-13 (Lunardi et al., 2013).

Campo (1987) and Stringfellow et al., found that viral replication in basal epithelial cells stimulates hyperproliferation and hyperplasia with formation of warts and benign papillomas. However, genetic or environmental factors might collaborate to become malignant.

Paintsil et al. and Veiga (1999) described wart-shaped with sharp, rough or wrinkly surfaces resembling a "cauliflower".

The fibropapillomas affect both dairy and beef cattle (Paintsil et al.; Veiga, 1999). When papillomas are located in the teats and udders, it makes milking difficult and can cause a drop in milk production predisposing to mastitis and spread of the virus through the perineum (Veiga, 1999, Campo, 2002). Jarret (1985) and Borzacchiello \& Roperto (2008) reported that lesions can induce to loss of reproductive function with consequent collapse and death of the animals. Young animals infected with these viruses and undergoing stressful confinement system, they become susceptible to secondary infections with significant weight loss and damage to the skin causing economic losses (Fenner, 1992; Veiga, 1999).

Some authors detected in bovine specie the presence of papillomavirus in skin as well as in semen, colostrum, urine, placenta, amniotic fluid, ovary and uterine mucosa (Carvalho, 2003; Yaguiu et al., 2006; Roperto et al., 2012). The transmission occurs through a direct contact from infected animals or indirectly through teat cup liners, drinkers, feeders, needles and syringes, handled when milk extraction and contaminated fences (Studdert et al., 1988; Yaguiu et al.). Arthropod vectors such as ticks can act as mechanical transmitters (Dalmat 1958; Somvanshi et al., 1986; Mbuthia et al., 1993). Preliminary studies indicate the presence of these viruses in the blood of cattle suggesting that this latent site may exert a role in the transmission of the disease (Diniz et al., 2009).
About $60 \%$ of Brazilian herd are infected by at least with one type of bovine papillomatosis virus (Stocco et al., 2003). The heavy traffic of animals between different regions of the country has contributed to the spread of this agent (Veiga, 1999).

In this study, we present ultrastructural aspects of virus in skin lesions in cattle population, in four outbreaks in Brazil.

The electron microscopy has been very helpful to identify several viral agents during outbreaks (Roingeard, 2008) being elected as an important tool in the study of viruses with icosahedral structure (Garcea \& Cahen, 2007).

\section{MATERIAL AND METHOD}

Description of the outbreaks. Four outbreaks of bovine papillomatosis occurred in 2000, in herds located in the city of Itarumã, GO, Igaratá, SP, Dourados, MS and Mogi Guaçu, SP, Brazil. The disease affected only females aging from 1-2 years and the lesions were located mainly in the teats and udders. In animals of the Dourados, MS, papillomas were also located in the head and neck. About $50-70 \%$ of the animals were contaminated, and in the Dourados, MS, two animals died. The skin fragments were randomly collected from different parts of the body, teats, udders, head and neck, who presented lesions. Ten samples of fragments of skin lesions from each herd, totaling 40 samples, were sent to the Electron Microscopy Laboratory of the Biological Institute, São Paulo, Brazil and were processed for transmission electron microscopy using negative staining (rapid preparation), resin embedding, immunoelectron microscopy and immunocytochemistry techniques. Macroscopically, it was observed that all the fragments had high density formation of irregular shape, roughly spherical, circunscribed and with diameter varying from 0.5 to $2 \mathrm{~cm}$. The surface of these lesions was wrinkled, cornified, grayish and lacking hair. Elevations and indentations determined the characteristic feature called "cauliflower".

Negative staining technique (rapid preparation). This technique was performed according to the methodology described by Brenner \& Horne (1959), Hayat \& Miller (1990) and Madeley (1997). Skin lesion fragments were suspended in phosphate buffer $0.1 \mathrm{M}$ and $\mathrm{pH} 7.0$, placed in contact with metallic copper grids with carbon stabilized supporting film of $0.5 \%$ collodium in amyl acetate. Next, the grids were drained with filter paper and negatively stained at $2 \%$ ammonium molybdate $\mathrm{pH} 5.0$. 
Resin embedding technique. Fragments of skin lesions were fixed in $2.5 \%$ glutaraldehyde in $0.1 \mathrm{M}$, $\mathrm{pH} 7.0$ phosphate buffer and post-fixed in $1 \%$ osmium tetroxide in the same buffer. After dehydration in cetonic series, the fragments were embedded in Spurr resin. Ultrathin sections were cut on the LKB ultratome and mounted on copper grids. The sections were contrasted with uranyl acetate-lead citrate (Watson, 1958; Reinolds, 1963).

Immunoelectron microscopy technique. In this technique, copper grids, previously prepared with collodion film and stabilized with carbon were first incubated with protein A $(1 \mathrm{ml} / \mathrm{ml})$, placed in contact with a virus-specific antibody. After this, the grids were washed in PBS drops, incubated with the viral suspension washed with drops of water and negatively stained with $2 \%$ ammonium molybdate, $\mathrm{pH} 5.0$ (Almeida \& Waterson,1969; Derrick, 1973; Berthiaume et al., 1981).

Immnunocitochemistry technique. At the immunolabeling technique with colloidal gold particles for negative staining, the copper grids were placed in contact with viral suspension and, after removing excess with filter paper, the same were put on specific primary antibody drops. After successive washings in PBS drops, the grids were incubated in protein A drops in association with $10 \mathrm{~nm}$ gold particles (secondary antibody). Grids were then contrasted at $2 \%$ ammonium molybdate, pH 5.0 (Knutton, 1995). Observations were made in a Philips EM 208 electron microscope, at $80 \mathrm{kV}$.

\section{RESULTS}

Negative staining technique (rapid preparation). In all suspension of skin lesion fragments negatively contrasted and examined under a transmission electron microscope, it was possible to observe papillomavirus particles, rounded, non-enveloped, arranged in groups, characterized as "full" (Fig. 1, arrow) and "empty" (fig. 3, arrow) with icosahedral symmetry, measuring about $60 \mathrm{~nm}$ in diameter.

Resin embedding technique. Ultrathin sections of fragments, revealed the presence of deformed nuclei with densely compacted chromatin (Figs. 3, 4, and 5), intranuclear spherical particles (figs. 2, 3, 4 and 5, big arrow) measuring $35 \mathrm{~nm}$ in diameter and tubular particles (fig. 5, minor arrow) from 35 to $39 \mathrm{~nm}$. The organelles were altered and empty (Figs. 3 and 4, blue arrow).

Immunoelectron microscopy technique. The presence of aggregates formed by antigen-antibody interaction conferred the positive result for the papillomavirus (Fig. 6).
Immnunocytochemistry technique. In this technique, the antigen-antibody reaction was marked by colloidal gold particles, strongly enhancing the viral particles (Fig. 7, arrow).

In all the 40 analyzed samples of skin fragments, the papillomavirus was detected.

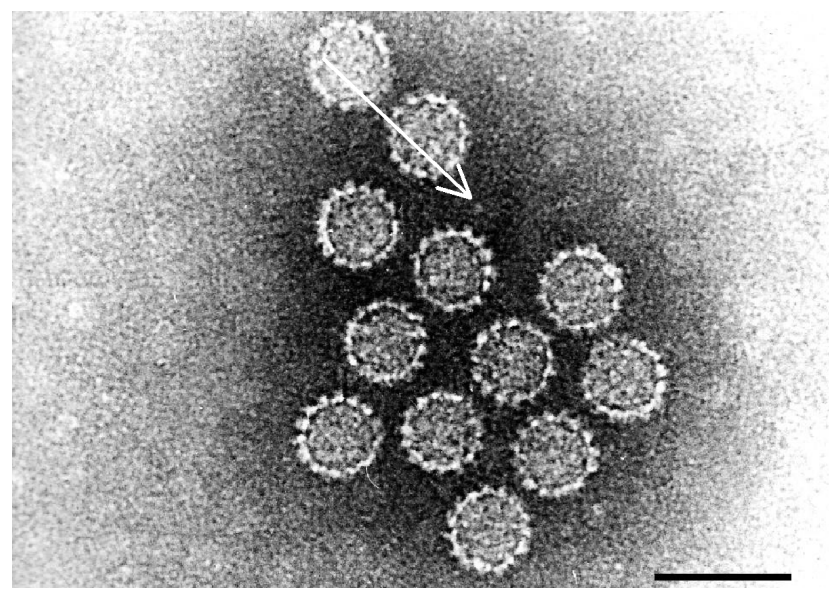

Fig.1. Negatively stained papillomavirus particles exhibit distinct, isolated capsomers (arrow). Bar: $70 \mathrm{~m}$.

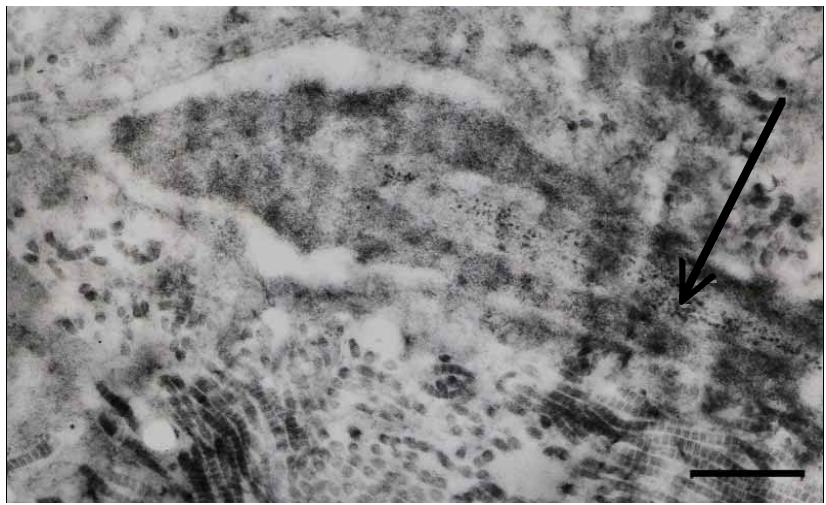

Fig. 2. Ultrathin section of the papilloma fragments. Papillomavirus intranuclear particles (arrow). Bar: $720 \mathrm{~nm}$.

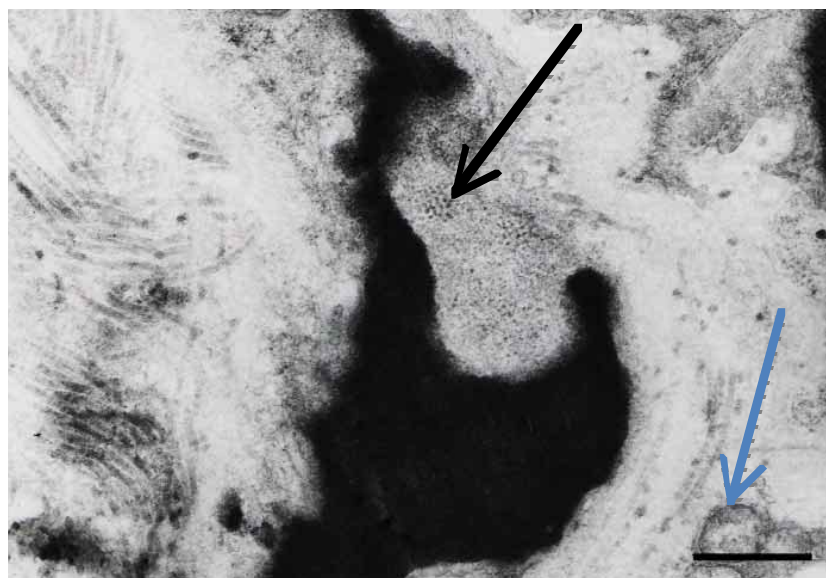

Fig. 3 - Ultrathin section of the papilloma fragments. Papillomavirus intranuclear particles (black arrow). Observe altered organelles and empty (blue arrow). Bar: $720 \mathrm{~nm}$. 


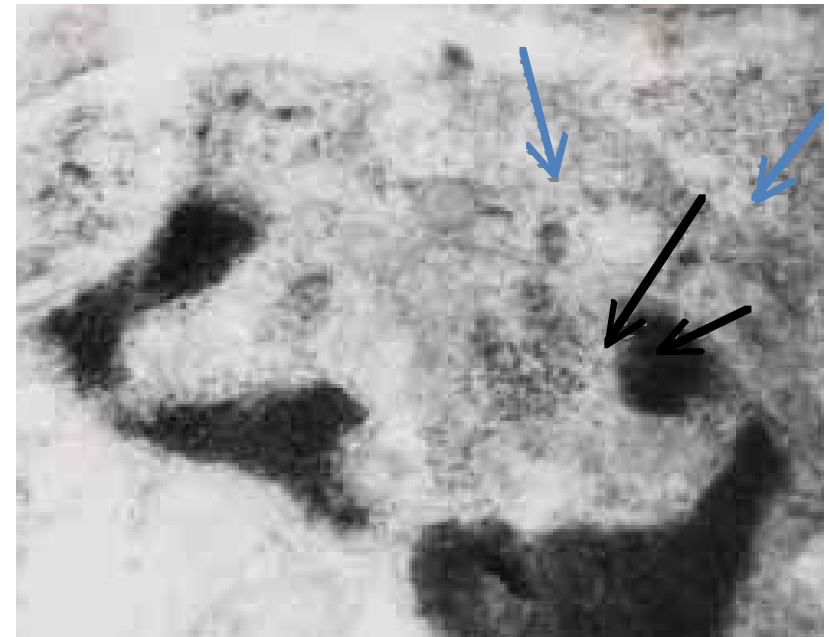

Fig. 4. Ultrathin section of the papilloma fragments. Papillomavirus intranuclear particles showing spherical particles (big black arrow) and tubular particles (minor black arrow). Observe altered organelles and empty (arrow blue). Bar: $500 \mathrm{~nm}$.

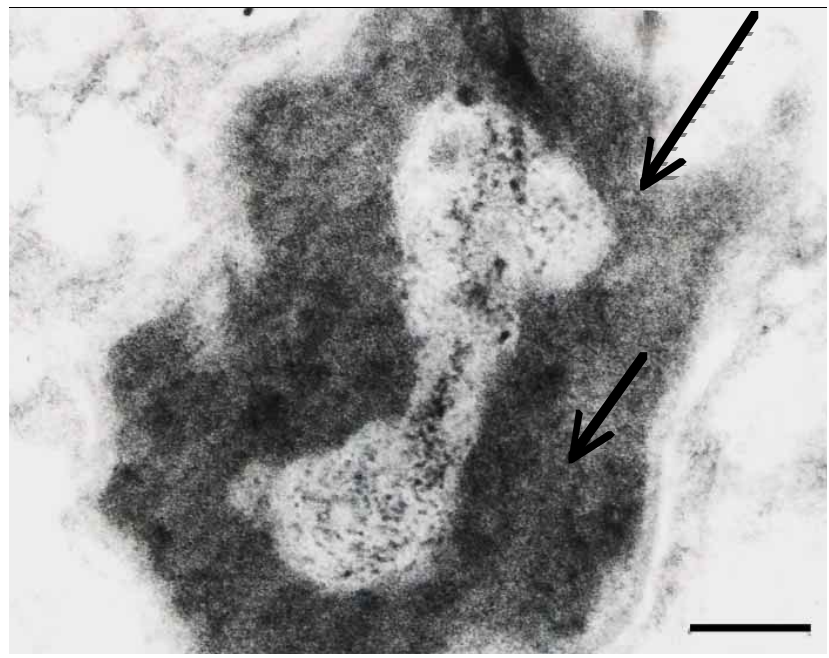

Fig. 5. Ultrathin section of the papilloma fragments. Papillomavirus intranuclear particles presenting spherical particles (big arrow) and tubular particles (minor arrow). Bar: $500 \mathrm{~nm}$.

\section{DISCUSSION}

The presence of papillomavirus in cattle herds during four outbreaks in Brazilian states was documented in this study under transmission electron microscopy techniques.

It was observed that only females had the disease, being these results in accordance with those of Maeda et al. (2007). In contrast, other studies have demonstrated the presence of papilloma in female and male bovine (Özsoy et al., 2011) and buffaloes (Nooruddin et al., 1989).

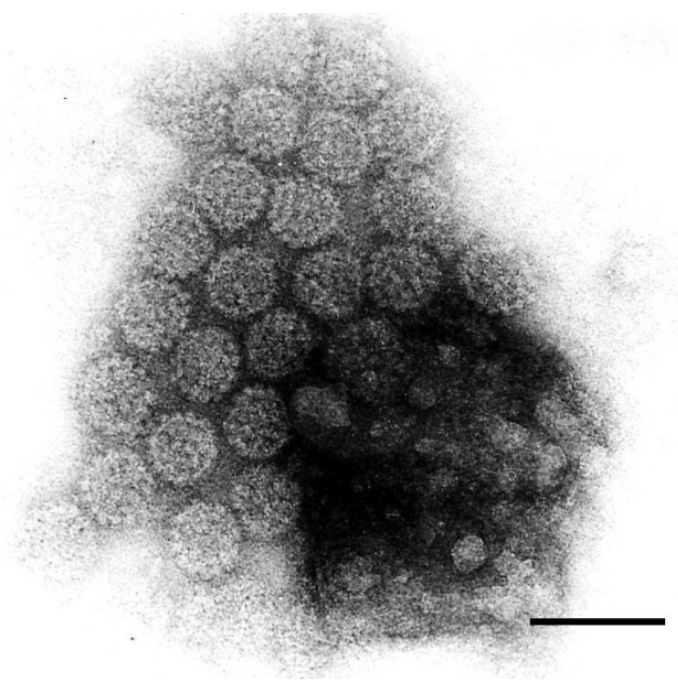

Fig. 6. Papillomavirus particles aggregated by antigen-antibody interaction. Bar: $80 \mathrm{~nm}$.

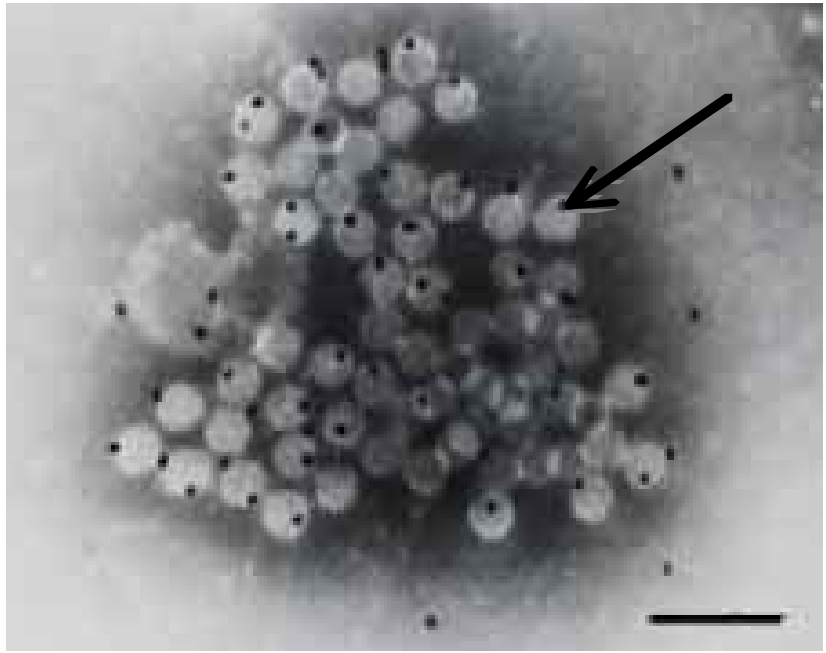

Fig. 7. Immunocytochemistry technique. Papillomavirus marked by the particles of colloidal gold (arrow). Bar: $130 \mathrm{~nm}$. 
reported to have found only in the teats of heifers. It has already been reported the appearance of lesions in the abdomen, shoulder, chest, flank, base of the horns, eyes, ears, tongue, dewlap, neck, jaw, hip, thigh, buttocks, vulva, rectum, knees and posterior back of cattle and buffaloes (Tweddle \& White, 1977; Cappellaro et al., 1978; Lancaster \& Olson, 1982; Nooruddin et al.; Julinek \& Tochezy, 2005; Turk et al.; Wosiacki et al.; Claus et al., 2007; Borzacchiello et al.; Özsoy et al.; Zhu et al.; Lunardi et al., Ford et al.).

Macroscopically, the papillomatous lesions exhibited circumscribed aspects, pedunculated, wrinkly surface, cornified, of grayish and lacking hair. These data are similar to other literature (Tweddle \& White, 1977; Cappellaro et al.; Jelinek \& Tachezy 2005; Turk et al.; Maeda et al.; Borzacchiello et al.; Öszoy et al.).

On the other hand, microscopic analysis of the lesions by negative staining technique revealed papillomavirus particles of spherical shape, measuring approximately 60 nm diameter, characterized as "full" and "empty" particles and containing capsomers of icosahedral symmetry. Similar results were also found in other studies with cattle (Tajima et al., 1968;Ford et al.; Zhou et al., 1993; Liu, 1998; Turk et al.; Mendonça \& Netto, 2005; Xu et al., 2006; Leishangthem et al., 2008; Silvestre et al., 2009), deer (Sundeberg et al., 1985a, b), felines (Sundberg et al., 2000) and humans (Buck et al., 2005).

It was not possible to observe through the negative staining technique variants and tubular particles described by Cheville \& Olson (1964) and Doane \& Anderson (1987). Groups of rounded, viral particles with a $35 \mathrm{~nm}$ in diameter were found intranuclearly in sections of ultrathin fragments, which confer the literature related to bovine (Tajima et al.; Zhou et al.; Jelinek \&Tachezy, 2005; Maeda et al.; Roperto et al.), dogs (Buff et al., 1988), deer (Sundberg et al., 1985b), cats (Sundberg et al.) and poultry (Daoust et al., 2000). Intracytoplasmic viral particles, cited by Jelineck \& Tachezy (2005) in cattle and by Sundberg et al., in cats were not observed in this study, even the crystalline arrangements described by Elzein et al., in cattle and by Sundberg et al., (1985b) in deer. However, cylindrical or tubular intranuclear structures were observed, according to Daoust et al. who studied lesions of birds.

The use of the immunoelectron microscopy techniques with the purpose of increasing the uptake of papillomavirus particles was demonstrated in several experiments in cattle (Gorra et al., 1985; Burkhardt et al., 1989), deer (Sundberg et al., 1985a); bird (Sironi \&Gallazi, 1992) and human (Anisimova et al., 1990; 1994; Daponte et al., 2003). In this technique positivity obtained is due to aggregation of viral particles formed by the antigen-antibody interaction.

The results using immunocytochemistry technique with bovine anti-papillomavirus antibody showed colloidal gold particles evenly distributed on viral surface.

Researchers using the same technique presented satisfactory results in bovine (Liu et al., 1997) and human (Palaniyandi et al., 2012).

The negative staining and resin-embedding techniques are preconized by Fenner et al. (1992), and Hazelton \& Gelderblomt (2003) as a simple, fast, and suitable to detect papillomavirus and through these we visualize great amount of viral particles.

The risk of cross-infection of bovine papillomatosis among other species can lead to a state of alert for the economy and public health. Serological studies performed by Buff et al., confirm the presence of mammary papilloma in a female dog due to cross-contamination with bovine fibropapilomavirus. Also Nasir \& Campo (2008) showed that the BPV-1 type infects horses and at times leading to death.

It is very important the adoption of prophylaxis and prevention measures, such as rigorous inspection when introducing animals in properties, isolation of sick animals, vaccination, sterilization of milking equipment, use of disposables such as needles and syringes, control of flies and ticks through the use of insecticides and to maintain good hygiene and biosecurity in the properties (Campo \& Jarret, 1994; Wadhwa et al., 1996; Maeda et al.).

Our study was a pioneer in Brazil to show the importance of using the transmission electron microscopy techniques as a routine diagnostic to detect bovine papillomatosis.

CATROXO, M.H.B.; MARTINS, A.M.C.P.F.; PETRELLA, S.; SOUZA, F.; NASTARI, B.D.B. Estudio ultraestructural del vírus del papiloma bovino durante los brotes de Brasil. Int. J. Morphol., 31(2):777-784, 2013.

RESUMEN: Los virus del papiloma que pertenecen a la familia Papillomaviridae son pequeños virus oncogénicos que causan papilomas y fibropapilomas en epitelio cutáneo y mucoso de distintas especies de animales. En el ganado vacuno, trece tipos (BPV- 1-13) se caracterizaron hasta el momento. En este estudio, se documenta la ocurrencia de cuatro brotes de papilomatosis en los rebaños de ganado, procedentes de estados brasileños. Las lesiones papilomatosas se localizaron en los pezones, la ubre, la ca- 
beza y el cuello. Al microscopio electrónico de transmisión, en la técnica de tinción negativa fueran visualizadas partículas del virus del papiloma redondeadas, con simetría icosaédrica, caracterizadas como "llenas" y "vacías", midiendo unos $60 \mathrm{~nm}$ de diámetro en todas las 40 muestras de fragmentos de lesión de piel estudiado. Los cortes ultra finos mostraron la presencia de grupos de partículas virales, intranucleares redondeadas con $35 \mathrm{~nm}$ de diámetro y tubulares 35-39 nm de diámetro. En la técnica de microscopía inmunoelectrónica, la positividad obtenida se caracterizó por la presencia de agregados de partículas virales formadas por la interacción antígeno-anticuerpo. En la aplicación de la técnica de inmunocitoquímica, la reacción antígeno-anticuerpo mostró partículas de oro coloidal distribuidos de manera uniforme sobre la superficie del virus. Estos resultados muestran la importancia de las técnicas de microscopía electrónica de transmisión en el diagnóstico de papilomatosis bovina, que pueden ser utilizados en los procedimientos de rutina para la identificación del agente viral causante de esta importante enfermedad.

PAlabras Clave: Papilomavirus, Ganado, Microscopía Electrónica de Transmisión.

\section{REFERENCES}

Almeida, J. D. \& Waterson, A. ,P. The morphology on virus - antibody interaction. Adv. Virus Res., 15:307-38, 1969.

Anisimová, E.; Barták, P.; Vlcek, D.; Hirsch, I.; Brichácek, B. \& Vonka, V. Presence and type specificity of papillomavirus antibodies demonstrable by immunoelectron microscopy tests in samples from patients with warts. J. Gen. Virol., 71:419-22, 1990.

Anisimov, E.; Barták, P.; Hamsiková, E. \& Vonka, V. Comparative sensitivity of the immunoelectronmicroscopy test and ELISA with intact virions in detecting HPV-1 antibodies and age distribution of these antibodies among general population and in children's homes. Arch. Virol., 137:157-60, 1994.

Berthiaume, L. \& Alain, R. M. A.; Laughlin, B.; Payment, P. \& Trepainer, P. Rapid detection of human viruses in feces by a simple and routine immune electron microscopy technique. J. Gen. Virol., 55:223-27, 1981.

Bloch, N.; Breeen, M. \& Spradbow, P.B. Genomic sequences of bovine papillomaviruses in formalin-fixed sarcoids from Australian horses revealed by polymerase chain reaction. Vet Microbiol., 41:163-72, 1994.

Borzacchiello, G. \& Roperto, F. Bovine papillomaviruses, papillomas and cancer in cattle. Vet. Res., 39(45):1-19, 2008.

Borzacchiello, G.; Roperto, F.; Nasir, L. \& Campo, M.S. Human papillomavirus research: do we still need animal models? Int. J. Cancer, 125(3):739-40, 2009.

Brenner, S. \& Horne, R. W. A negative staining method for high resolution electron microscopy of viruses. Biochem. Biophys. Acta., 34:103, 1959.
Buck, C. B.; Thompson, C. D.; Pang, Y. Y.; Lowy, D. R. \& Schiller, J.T. Maturation of papillomavirus capsids. J. Virol., 79:2839-46, 2005.

Buff Jr., W.; Mueller, S.B.K.; Cappellaro, C.E.M.P.D.M.; Catroxo, M.H.B. \& Esteves, R. Estudo de papilomatose cutânea de bovinos - ocorrência atípica em cão. Rev. Bras. Med. Vet., 10:33-6, 1988.

Burkhardt, A.; Willingham, M.; Gay, C.; Jeang, K.T. \& Schlegel, R. The E5 oncoprotein of bovine papillomavirus is oriented asymmetrically in Golgi and plasma membranes. Virol., 170:334-9, 1989.

Campo, M.S. Papillomas and cancer in cattle. Can. Surv., 6:39-54, 1987.

Campo, M. S. \& Jarret, W.F. Vaccination against cutaneous and mucosal papillomavirus in cattle. Ciba Found Symp. 187:61-73, 1994.

Campo, M.S. Review bovine papillomavirus and cancer. Vet. J., 154:17588, 1997.

Campo, M.S. Animal models of papillomavirus pathogenesis. Virus Res., 89:249-61, 2002.

Cappellaro, C. E. M. P. D. M.; Ribeiro, L. O. C.; Mueller, S.B. K. \& Piegas, N.S. Estudo da morfologia e histopatologia de diferentes tipos de papilomas bovinos. Biológico, 44:307-16, 1978.

Carvalho, C.; Freitas, A. C.; Brunner, O.; Góes, L.G.B.; Cavalcante, A.Y.; Beçak, W. \& Stocco dos Santos, R.C. Bovine papillomavirus type 2 in reproductive tract and gametes of slaughtered bovine females. $\mathrm{Braz}$. J. Microbiol., 34:82-4, 2003.

Cheville, N.F. \& Olson, C. Epithelial and fibroblastic proliferation in bovine cutaneous papillomatosis. Path. Vet., 1:248-57, 1964.

Claus, M.P.; Vivian, D.; Lunardi, M.; Alfieri, A.F. \& Alfieri, A.A. Análise filogenética de papilomavírus bovino associado com lesões cutâneas em rebanhos do Estado do Paraná. Pesq. Vet. Bras., 27:314-18, 2007.

Corteggio, A.; Altamura, G.; Roperto, F. \& Borzacchiello, G. Bovine papillomavirus E5 and E7 oncoproteins in naturally occurring tumors: are two better than one? Infect. Agents and Cancer, 8:1-9, 2013.

Dalmat, H.T. Arthropod transmission of rabbit papillomatosis. J. Exptl. Med., 108:9-20, 1958.

Daoust, P-Y.; Wadowska, D.; Kibenge, F.; Campagnoli, R.P.; Kenneth S.; Latimer, K.S. \& Ritchie, B.W. Proliferative pododermatitis associated with virus-like particles in a Northern Gannet. J. Wildl. Dis., 36(2):378-82, 2000.

Daponte, A.; Grayson, W.; Moisuc, D.; Ebrahim, S. \& Guidozzic, F. Adenoid cystic carcinoma stage Ib1 treated with radical surgery displaying human papilloma virus 33 (HPV 33): immunoelectron microscopy and review. Gynecol. Oncol., 90:673-6, 2003.

Derrick, K.S. Quantitative assay for plant viruses using serologically specific electron microscopy. Virol., 56:652-3, 1973.

Diniz, N.; Melo, T. C.; Santos, J. F.; Mori, E.; Brandão, P. E.; Richtzenhain, L. J.; Freitas, A.C.; Beçak, W.; Carvalho, R.F. \& Stocco, R.C. Simultaneous presence of bovine papillomavirus in blood and in short-term lymphocyte cultures from dairy cattle in Pernambuco, Brazil. Gene. Mol. Res., 8:1474-80, 2009. 
Doane, F. W. \& Anderson, M. Electron microscopy in diagnostic virology - A pratical guide and atlas. Cambridge University Press, Cambridge, 1987, 178p.

Dong, J.; Zhu, W.; Goto, Y. \& Haga, T. Initial Detection of a Circular Genome Deletion in a Naturally Bovine Papillomavirus-Infected Sample. J. Vet. Med. Sci., 75(2):179-82, 2013.

Doobar, J. \& Sterling, J.C. The biology of human papillomaviruses. In Sterling, J.C. \& Tying, S.K. (edit), Human papillomaviruses clinical and scientific advances Londres, Arnold, p.10-23, 2001.

Elzein, E.T.; Sundberg, J.P.; Housawi, F.M.; Gameel, A.A.; Ramadan, R.O. \& Hassanein, M.M. Genital bovine papillomavirus infection in Saudi Arabia. J. Vet. Diagn. Invest., 3:36-8, 1991.

Fenner, F., Bachmann, P. A.; Gibbs, E. P. J.; Murphy, F.A.; Studdert, M. J. \& White, D. O. Virologia Veterinária. Acribia, Zaragoza, 1992. $691 \mathrm{p}$.

Ford, J. N.; Jennings, P.A.; Spradbow, P. B. \& Francis, J. Evidence for papillomaviruses in ocular lesions in cattle. Res. Vet. Sci., 32:2579, 1982.

Garcea, R. L. \& Chen, X. Papillomavirus structure and assembly. In: R. L. Garcea \& D. DiMaio (eds.), The papillomaviruses, Springer, New York, 2007, p.69-88.

Gorra, J. B.; Wayne, D.; Lancaster, W. D.; Kurman, R. J. \& Jenson, A.B. Bovine papillomavirus type 1 monoclonal antibodies. $J N C I$ J. Natl. Cancer Inst., 75(1):121-5, 1985.

Gonzales-Santander, R. Técnicas de microscopia eletrônica en biología. Madrid, Ed. Aguilar, 1969, 666 p.

Hatama, S.; Nobumoto, K. \& Kanno, T. Genomic and phylogenetic analysis of two novel bovine papillomaviruses, BPV-9 and BPV10. J. Gen. Virol., 89:158-63, 2008.

Hatama, S.; Ishihara, R.; Ueda, Y.; Kanno, T. \& Uchida, I. Detection of a novel bovine papillomavirus type 11 (BPV-11) using xipapillomavirus consensus polymerase chain reaction primers. Arch. Virol., 156:1281-5, 2011.

Hayat, M. A. \& Miller, S. E. Negative Staining. Mc. Graw-Hill Publ. Company., 1990. 235p

Hazelton, P.R. \& Gelderblomt, H.R. Electron microscopy for rapid diagnosis of emerging infectious agents. Emerg. Infect. Dis., 9(3):294303, 2003.

Jarrett, W. F. H.; Campo, M. S.; Oweil, B. W.; Laird, H. M. \& Coggins. L.W. A novel bovine papillomavirus (BPV-6) causing true epithelial papillomas of the mammary gland skin: A member of a proposed new BPV subgroup. Virol., 136(2):255-64, 1984.

Jarrett, W. F. H. The natural history of bovine papillomavirus infections. Adv.Viral Oncol., 5:83-102, 1985.

Jelineck, F. \& Tachezy, R. Cutaneous papillomatosis in cattle. J. Comp. Pathol., 132:70-81, 2005.

Knutton, S. Electron microscopical methods in adhesion. Meth. Enzymol., 253:145-58, 1995.
Lancaster, W.D. \& Olson, C. Animal papillomaviruses. Microbiol. Rev., 46:191-207, 1982

Leishangthem, G. D.; Somvanshi, R. \& Tiwari, A.K. Detection of bovine papillomaviruses in cutaneous warts papillomas in cattle. Indian $J$. Vet. Pathol., 32(1):15-20, 2008

Liu, W. J.; Gissmann, T.; Sun, X. Y.; Kanjanahaluethai, A.; Ller, M. M.; Doorbar, J. \& Zhou, J. Sequence close to the N-terminus of L2 protein is displayed on the surface of bovine papillomavirus type 1 virions. Virol., 227:474-83, 1997.

Liu, X.S.; Abdul-Jabbar, I.; Qi, Y. M., Frazer, I. H. \& Zhou, J. Mucosal immunisation with papillomavirus virus-like particles elicits systemic and mucosal immunity in mice. Virol., 252:39-45, 1998.

Luft, J. A. Improvements in an epoxy resin embedding methods. J. Biophys. Biochem. Cytol., 9:409-14, 1961.

Lunardi, M.; Alfieri, A. A.; Otonel, R. A. A.; Alcântara, B. K.; Rodrigues, W. B.; Miranda, A. B. \& Alfieri, A.F. Genetic characterization of a novel bovine papillomavirus member of the Deltapapillomavirus genus. Vet. Microbiol., 162:207-13, 2013.

Madeley, C. R. Electron microscopy and virus diagnosis. J. Clin.Pathol., 50:454-6, 1997

Maeda, Y.; Shibahara, T.; Wada, Y.; Kadota, K.; Kanno, T.; Uchida, I. \& Hatama, S. An outbreak of teat papillomatosis in cattle caused by bovine papilloma virus (BPV) type 6 and unclassified BPVs. Vet. Microbiol., 121:242-48, 2007.

Mbuthia, G. P.; Ngatia, T. A. \& Wamokoy, J. P. O. Ocorrence of bovine skin diseases in Kenya. Bull. Anim. Prod. Afr., 41:311-6, 1993.

Mendonça, M. L. \& Netto, J. C. A. Importância da infecção pelo papilomavírus humano em pacientes do sexo masculino. DST - $J$. bras. Doenças Sex. Transm., 17(4): 306-10, 2005.

Modis, Y.; Trus, B. L. \& Harrison, S. C. Atomic model of the papillomavirus capsid. EMBO J., 21:4754-62, 2002.

Nasir, L. \& Campo, M.S. Bovine papillomaviruses: their role in the aetiology of cutaneous tumours of bovids and equids. Vet. Dermatol., 19:243-54, 2008.

Nooruddin, M.; Singh, K.B. \& Nauriyal, D.C. Cutaneous papillomatosis (warts) in buffaloes. Buffalo Bull., 8:37-42, 1989.

Ogawa, T.; Tomita, Y.; Okada, M.; Shinozaki, K.; Kubonoya, H.; Kaiho, I. \& Shirasawa, H. Broad-spectrum detection of papillomaviruses in bovine teat papillomas and healthy teat skin. J. Gen. Virol., 85:21917, 2004.

Ozsoy, S. Y.; Ozyildiz, Z. \& Guzel, M. Clinical, pathological and immunohistochemical findings of bovine cutaneous papillomatosis. Ankara Univ. Vet. Fak. Derg., 58:161-5, 2011.

Paintsil, J.; Muller, M.; Picken, M.; Gissman, L. \& Zhou, J. Calcium is required in reassembly of bovine papillomavirus in vitro. J. Gen. Virol., 79:1133-41, 1998

Palaniyandi, M.; Kato, T. \& Park, E.Y. Expression of human papillomavirus 
6b L1 protein in silkworm larvae and enhanced green fluorescent protein displaying on its virus-like particles. Springer Plus., 1:29, 2012.

Patel, K. R.; Smith, K. T. \& Campo, M. S. The nucleotide sequence and genome organization of bovine papillomavirus type 4. J. Gen. Virol., 68: 2117-28, 1987.

Pfister, H.; Linz, U.; Gissmann, L.; Huchthausen, H.; Hoffmann, D. \& Hausen, H.Z. Partial Characterization of a New Type of Bovine Papilloma Viruses. Virol., 96:1-8, 1979.

Reynolds, E. S. The use of lead citrat of high $\mathrm{pH}$ as an electron-opaque stain in electron microscopy. J. Cell. Biol., 17:208-12, 1963.

Roingeard, P. Viral detection by electron microscopy: past, present and future. Biol.Cell., 100(8):491-501, 2008.

Roperto, S.; Borzacchiello, G.; Esposito, I.; Riccardi, M.; Urraro, C.; Luca, R.; Corteggio, A.; Tate, R.; Cermola, M.; Paciello, O. \& Roperto, F. Productive Infection of Bovine papillomavirus type 2 in the placenta of pregnant cows affected with urinary bladder tumors. PLOS ONE, 7(3):1-9, 2012.

Schuch, L. F. D. Papilomatose bovina. In: Riet-Correa, F.; Schild, A.L. \& Mendez, M.D.C. Doenças de ruminantes e equinos. Ed. Universitária (UFPel), Pelotas, 1998. p.651.

Shah, K.V. \& Howley, P. M. Papillomaviruses. In: Fields, B.N.; Knipe, D.M. Virology. 2 Ed. Raven Press Ltda, New York, 1990. cap. 59.

Silvestre, O.; Borzacchiello, G.; Nava, D.; Iovane, G.; Russo, V.; Vecchio, D.; D'ausilio, F. Gault, E. A.; Campo, M. S. \& Paciello, O. Bovine Papillomavirus Type 1 DNA and E5 Oncoprotein Expression in Water Buffalo Fibropapillomas. Vet. Pathol., 46:636-41, 2009.

Sironi, G. \& Gallazzi, D. Papillomavirus infection in greenfinches (Carduelis chloris). Zentralbl. Veterinarmed. B., 39(6):454-8, 1992.

Somvanshi, R.; Koul, G.L.; Sharma, B. \& Biswas, J.C. Clinicopathological observations of cutaneous bovine papillomas. Indian J. Anim. Sci., 56:836-40, 1986

Stocco, R.C. ; Freitas, A. C. ; Carvalho, C. ; Beçak, W. Papilomatose infecta $60 \%$ do rebanho bovino. Veterinária in Foco, São Paulo, v.1, ed., 09 out., 2003.

Studdert, M. J.; Mccoy, K.; Allworth, M. B. \& Staples, P. papilloma of the ears of calves following tattooing. Aust. Vet., 65:399, 1988.

Sundberg, J. P.; Williams, E. S.; Hill, D.; Lancaster, W. D. \& Nielsen SW. Detection of papillomaviruses in cutaneous fibromas of white-tailed and mule deer. Am. J. Vet. Res., 46(5):1145-9, 1985a.

Sundberg, J. P.; Hill, D. L.; Willians, E. S. \& Nielsen, S. W. Light and electron microscopic comparisons of cutaneous fibromas in white-tailed and mule deer. Am. J. Vet. Res., 46:2200-6, 1985b.

Sundeberg, J. P.; Van Ranst, M.; Montali, R.; Homer, B. L.; Miller, W. H.; Rowland, P. H.; Scott, D. W.; England, J. J.; Dunstan, R. W.; Mikaelian, I. \& Jenson, A.B. Feline papillomas and papillomaviruses. Vet. Pathol., $37: 1-10,2000$.

Tajima, M.; Gordon, D. E. \& Olson, C. Electron microscopy of bovine papilloma and deer fibromaviruses. Am. J. Vet., 29:1185-94, 1968.
Turk, N.; Zupancic, Z.; Staresina, V.; Kovac, S.; Babic, T.; Kreszinger, M.; Curic, S.; Barbic, L. \& Milas, Z. Severe bovine papillomatosis: detection of bovine papillomavirus in tumour tissue and efficacy of treatment using autogenous vaccine and parammunity inducer. Veterinarski Archiv., 75(5):391-7, 2005.

Tweddle, N.E. \& White, W.E. An outbreak of anal fibropapillomatosis in cows following rectal examinations. Aust. Vet. J., 53(10):492-5, 1977.

Van Regenmortel, M. H. V.; Fauquet, C. M.; Bishop, D. H. L.; Carstens, E. B. Estes, M.K.; Lemon, S. M.; Maniloff, J.; Mayo, M. A.; McGeoch, D. J.; Pringle, C. R. \& Wickner, R. B. Virus taxonomy: The Classification and Nomenclature of Viruses. The Seventh Report of the International Comittee on Taxonomy of Viruses (book). Academic Press, San Diego, EUA, 2000. 1162 pp.

Veiga, V.M.O. Papilomatose: prejuízos não está só na aparência. Revista Balde Branco. 414, 1999.

Xu, Y-F.; Zhang, Y-Q.; Xu, X-M. \& Song, G-X. Papillomavirus virus-like particles as vehicles for the delivery of epitopes or genes. Arch. Virol.,151:2133-48, 2006.

Wadhwa, D. R.; Prasad, B.; Rao, V. N. \& Dhaliwa, A. S. Clinic-therapeutic and histopatologic studies on bovine cutaneous papillomatosis. Indian J. Dairy Sci., 49(3):206-8, 1996.

Watson, M. L. Staining of tissue sections for electron microscopy with heavy metals. J. Biophis. Biochem. Cytol., 4:475-8, 1958.

Wosiacki, S. R.; Reis, A. C. F.; Alfieri, A.F. \& Alfieri, A. A. Papilomavírus bovino tipo 2 na etiologia da hematúria enzoótica bovina. Sêmina, Ciências Agrárias, 23:121-30, 2002.

Wosiacki, S. R.; Barreiro, M. A. B.; Alfieri, A. F. \& Alfieri, A. A. Seminested PCR for detection and typing of bovine papillomavirus type 2 in urinary bladder and whole blood from cattle with enzootic haematuria. J. Virol. Methods., 126:215-9, 2005.

Yaguiu, A.; Carvalho, C. C.; Freitas, A. C.; Goes, L. G. B.; Dagli, M. L. Z.; Birgel Jr. E. H.; Becak, W. \& Stocco dos Santos, R. C. Papillomatosis in cattle: in situ detection of bovine papillomavirus DNA sequences in reproductive tissues. Braz. J. morphol. Sci., 23(3-4):525-9, 2006.

Zhou, J.; Stenzel, D. J.; Sun, X.-Y. \& Frazer, I. H. Synthesis and assembly of infectious bovine papillomavirus particles in vitro. J. Gen. Virol. 74(4):763-8, 1993

Zhu, W.; Dong, J.; Shimizu, E.; Hatama, S.; Kadota, K.; Goto, Y. \& Haga, T. Characterization of novel bovine papillomavirus type 12 (BPV-12) causing epithelial papilloma. Arch. Virol., 157:85-91, 2012.

\section{Correspondence to:}

Prof. Dr. Marcia Catroxo

Electron Microscopy Laboratory

Research and Development Center in Animal Healthy

Biological Institute of São Paulo

Av. Conselheiro Rodrigues Alves, 1252

Vila Mariana, São Paulo, SP

BRAZIL

Email: catroxo@biologico.sp.gov.br

Received: 02-02-2013

Accepted: 26-04-2013 